\title{
The Influence of Entrepreneurial Supports on Business Performance among Rural Entrepreneurs
}

\author{
Md Lazim Mohd Zin* and Hadziroh Ibrahim \\ School of Business Management, Universiti Utara Malaysia, Malaysia \\ lazim@uum.edu.my; hadziroh@uum.edu.my \\ *Correspondence: lazim@uum.edu.my
}

Received: $30^{\text {th }}$ July 2019; Accepted: $4^{\text {th }}$ December 2019; Published: $1^{\text {st }}$ February 2020

Abstract: The present study attempts to provide empirical evidence on the relationship between the four facets of entrepreneurial supports and rural entrepreneurs business performance. The entrepreneurial supports considered in the study are entrepreneurship training, marketing support, business networking, and financial support. A survey among 183 rural entrepreneurs was carried out. Self-reported measures were used to obtain data pertaining to government entrepreneurial initiatives and rural entrepreneurs' business performance. The multiple regression analysis was used to ascertain the proposed relationships and it was found that all entrepreneurial initiatives such as entrepreneurship training, marketing support, business networking and financial support were significantly related to business performance. Discussion on the findings is highlighted, so as the implications for practice and future research. Towards the end, the paper also highlights limitations of the study that could be taken into consideration by future scholars for further empirical enrichment.

Keywords: Entrepreneurship training; Marketing support; Business networking; Financial support; Rural entrepreneurs

\section{Introduction}

Small and medium enterprises (SMEs) are a primary engine of economic growth and a vital contributor to the overall performance of the Malaysian economy. Despite of its economic potential, rural micro enterprises have a number of constraints such as low level of productivity, inconsistent supply of raw materials, low and inefficient production level, outdated processing method and equipment, poor quality of food products and product packaging, poor hygiene and sanitary practices, lack of product development and marketing strategy (Norhaziah \& Mohd Noor, 2011). Acknowledging the limitations faced by this group of entrepreneurs, various government initiatives have been introduced to provide the necessary assistance for SMEs companies especially those involved in rural business. For instance, some form of financial assistance for rural entrepreneurs is

Md Lazim Mohd Zin and Hadziroh Ibrahim, "The Influence of Entrepreneurial Supports on Business Performance among Rural Entrepreneurs", Annals of Contemporary Developments in Management \& HR (ACDMHR), Print ISSN: 2632-7686, Online ISSN: 2632-7694, pp. 31-41, Vol. 2, No. 1, $1^{\text {st }}$ February 2020, Published by International Association of Educators and Researchers (IAER), DOI: 10.33166/ACDMHR.2020.01.004, Available: http://acdmhr.theiaer.org/archive/v2/v2n1/p4.html. 
given by the Malaysian government to enable them to purchase machines and equipment that would help their business reach a maturity stage (Siwar et al., 1994). The following are other forms of support programs initiated by the government to assist rural enterprises:

1. Rural Economy Funding Scheme (SPED) is a special funding for rural entrepreneurs to purchase machines/equipment, procure raw materials, and renovate or upgrade the premise of the business and industry.

2. Rural Transformation Centre (RTC) is a site to implement integrated initiatives, introduced by the government under the National Blue Ocean Strategy 4 (NBOS4). These initiatives are meant for rural enterprises located within the $100 \mathrm{~km}$ radius of the RTC. For instance, in the processing of agro-food products, rural entrepreneurs are supported in the development of their products through branding, labeling, packaging and certification with the help of various agencies, including the Federal Agricultural Marketing Authority (FAMA), Malaysian Agricultural Research and Development Institute (MARDI) and Department of Health.

3. Marketing of Bumiputera Entrepreneurs' Products in Hypermarket Scheme has the aim to help and introduce Bumiputera entrepreneurs' products in hypermarkets. It also aims to give an opportunity to Bumiputera entrepreneurs to sell and penetrate their products nationally and internationally.

4. Glokal Entrepreneur Program is an approach adopted by the Ministry of Entrepreneurial and Co-operative Development (MeCD) to develop more internationally recognised entrepreneurs.

Entrepreneur business performance has been generally measured in economic or financial terms such as return on assets, sales, profits, employees and survival rates, and non-pecuniary terms, such as, customer satisfaction, personal development and personal achievement (Hyvonen, 2007; Teoh \& Chong, 2008; Radiah et al., 2009; Reijonen, 2008). In this study, we defined business performance in terms of financial profit. The importance of government assistance for rural business success is reported in number of studies (Abd. Razak et al., 2012; Samujh, 2008). According to Samujh, rural entrepreneurship business performance is dependent on financial and non-financial support from government. Generally, support system for rural entrepreneurs such as market development, business network, accesses to finance, business training, and business supports are crucial in providing conducive business environment.

The question remains as to what extent the government assistance and support is effective in helping rural enterprises to achieve its business outcomes? To date, studies that looked at the contribution of government support to the development of rural enterprises are unfortunately lacking, despite the various initiatives have been implemented to assist the entrepreneurs. Previous studies on the business performance of rural entrepreneur has focused primarily on the entrepreneurial, managerial or other personality attributes of the business owner (Siwar et al., 1994). Some of the studies had also described the opportunities and constraints faced by micro entrepreneurs (Abd Razak, Mohd Hassan, Kamariah, \& Wan Fauziah, 2012; Mohd Noor Hakimin \& Mohd Rafi, 2010; Nurbani et al., 2011; Radiah, Mohd Rosli, \& Ab Azid, 2009). Therefore, this study aims to investigate the influences of four entrepreneurial initiatives such as entrepreneurship training, financial support, marketing support and business networking on business performance among rural entrepreneurs. 


\section{Literature Review and Hypothesis Development}

\subsection{Entrepreneurship Training and Business Performance}

The linkage between entrepreneurship training and rural entrepreneurs' performance can be justified in three interesting foundations (Kuene, 2008; Solomon, 2004; Smith \& Perks, 2006). For instance, Solomon (2004), in his study on entrepreneurial training, discovered the need for entrepreneurial skills and business skills for boosting the business performance. Meanwhile, Kuene (2008) argued that entrepreneur's knowledge and skills are significant determinants of business success. Training for small business is primarily internally focused and imparts generic management skills such as marketing, finance, record-keeping, human relations, as well as industrial relations (Solomon, 2004). In similar vein, entrepreneurial training is vital strategy for improving SME performance over time, showing that the business and the entrepreneurial skills are strongly correlated to business performance (Smith \& Perks, 2006). Furthermore, research found that entrepreneurship training contributed significantly to risk taking attitudes, the formation of new businesses (Umrani, Kura \& Ahmed, 2018; Garavan \& O'Cinnelde, 1994; Charney \& Libecap, 2002). Entrepreneurship training also seems to have a positive effect on the perceived feasibility of entrepreneurship, or on entrepreneurial self-efficacy (Alberti, Sciascia, \& Poli, 2005; Hytti, 2008, Lepoutre, Berghe, Tilleuil, \& Crihns, 2010). As such, it is hypothesized that:

H1: Entrepreneurship training has positive influence on business performance.

\subsection{Financial Support and Business Performance}

Almost every entrepreneur needs a substantial finance input. The financial resources for starting entrepreneurs are important. Small entrepreneurial firms including micro-businesses like rural entrepreneurs represent a strikingly large portion of the Malaysian economy. Basic indicators such as GDP growth, job creation, innovation rate, and wealth accumulation all depends to a great extent on the success of newly founded organizations constantly revitalizing Malaysian markets. Given the collective size and dynamism of this sector of the economy, the role of financial institutions in funding such firms have become a central area of research and debate.

It is argued that funding will have a large impact on the rural entrepreneur's success, as loans constitute a major source of entrepreneurial financing (Robb \& Robinson, 2014), and early-stage credit may enable rural entrepreneurial ventures to invest in value-creating opportunities and achieve necessary scale. The unavailability of funding to rural entrepreneurs may result in self-fund using retained earnings (i.e., bootstrap) or by having recourses to family wealth. According to Jones and Parry (2011), governmental financial support for developing small ventures becomes an essential input for their long-term economic prosperity. Consistently, Skuras, Caldas, Meccheri, Psaltopoulos, and Viladomiu (2003) maintained that governments could influence the market mechanisms and make them function efficiently by removing conditions that create market imperfections and administrative rigidities. They can also create an "enterprise culture" that enables firms to take reasonable risks and seek profits. Government support for entrepreneurship through financial initiative is very crucial to promote the entrepreneurial development and to ensure rural entrepreneurs' future business success. In this regard, business support is one way of improving and sustaining business growth (Jones \& Parry, 2011). Governments have a central role in supporting 
ventures whose success potential is not necessarily visible in the short term, but which may have a significant contribution to economic development. Hence, the following hypothesis is posited:

H2: Financial support has positive influence on business performance.

\subsection{Marketing Support and Business Performance}

Marketing support provided by the government has been crucial in assisting rural entrepreneurs (Hoe et al., 2012). Marketing accessibility is one aspect of marketing support which is crucial for success of rural entrepreneurs. This is represented by good networks with supermarket, accessibility of products into supermarket and tourist centres, establishing good networks with wholesaler and retailers, offering comparable quality of products, the ability to penetrate niche market, and grabbing market opportunity (Pech \& Cameron, 2006). Skuras et al., (2003) mentioned that, government could influence the market mechanisms and make them function efficiently by removing conditions that create market imperfections and administrative rigidities. They can also create an "enterprise culture" that enables firms to take reasonable risks and seek profits. In Malaysia, the government has introduced a support program to assist rural enterprises by providing access to hypermarkets so that they could sell and promote their products locally and internationally. With such marketing program, the following hypothesis is posited:

H3: Marketing support has positive influence on business performance.

\subsection{Business Networking and Business Performance}

The influence of business networking on business performance can be justified in many ways. For instance, according to Gilmore et al. (2006), business networking is recognised as an activity that can help SMEs to utilize their limited resources and compete more effectively with their competitors. In similar vein, business networking can provide value to members by allowing them access to the social resources embedded within a network; that is, networking can provide the means by which rural entrepreneurs can tap needed resources that are 'external' to the firm (Florin, Lubatkin, \& Schulze, 2003; Jarillo, 1989). According to Julien (1993), business networking can facilitate the achievement of economies of scale in rural entrepreneurs without producing the diseconomies caused by large size. This is consistent with an underlying assumption of Resource-based View Theory (Barney, 1991). According to RBV theory, firms with valuable, rare, and inimitable resources (including non-substitutability) have the potential for achieving superior performance (Barney, 1991). In this context resources obtained through business networking is useful for developing long-term competitive advantages.

On the other hand, many researchers on business performance believes that through business networking, entrepreneurs can have access to relevant information, technology, financial and nonfinancial resources, which in turn can boost their business performance (Burt, 1997; Granovetter, 1992; Neergard, Shaw, \& Carter, 2005; Van de Ven, Hundson, \&Schroeder, 1984). For example, Van de Ven, Hundson, and Schroeder (1984) found that high performing entrepreneurs tended to be more engaged in complex business networking with people both inside and outside of the firm. Using business networks can, therefore, potentially lower a firm's risk of 'failure' and increase its chances of successes in the future. As such, hypothesis is stated as follow:

H4: Business networking has a positive influence on business performance. 


\section{Methodology}

Population in the current study is five-hundred rural entrepreneurs who participated in the Rural Entrepreneurs Carnival organized by the Ministry of Rural and Regional. The rural entrepreneurs in the present study were involved in a diverse range of businesses such as cosmetic, craft, herbs, food and drinks, agriculture, and textile, among others. Prior to data collection, written permission from the carnival organizer to collect data from rural entrepreneurs was obtained. Purposive sampling was used to determine the sample for the study. The sample was made up of 132 (72.13\%) female and 51 (27.87\%) male entrepreneurs. The gender distribution of rural entrepreneurs was consistent with prior studies (Fatimah et al., 2013; Musdiana \& Noor Zahirah, 2011; Radiah et al., 2009; Zumilah, 2012).

In general, female entrepreneurs are said to be the dominant player especially in micro and small businesses in Malaysia (Hoe et al., 2012; Nor Haryanti, Siti Norbaya, Rabihah, Fadhilah, \& Mohd Sazali, 2012). In addition, 53.0\% were married, and were relatively educated with almost half had completed their higher school education. Almost half of the participants had between four and seven years of experience in running their business and were involved in food business. The majority of them employed between two and seven employees. In general, cosmetic business recorded the highest profit (mean = RM71,923.08/year), while rural entrepreneurs in health-related products recorded the lowest profit (mean $=$ RM20,200.00/year).

\subsection{Measurements}

Literature refers predominantly to financial criteria when measuring business success (Reijonen, 2008). Consistently, we measured business performance by looking at business profit (Reijonen, 2008). In this study, participants were asked to indicate their estimated business profit for 2013, 2012, and 2011.

Entrepreneurship training was operationalized as education and training programs for entrepreneurs that focus on ensuring growth and feature development of the business (Petridou \& Glaveli, 2008). Entrepreneurship training was measured using 10 items adapted from Rogoff, Lee, and Suh (2004), and Petridou and Glaveli (2008). Participants were asked to indicate their level of agreement or disagreement on whether the government provides such training on "comprehensive marketing course" and "technical and skills in business management'. A five-point Likert scale with anchors ranging from ' 1 ' "strongly disagree" to ' 5 ' "strongly agree" was used to measure entrepreneurship training.

Accordingly, marketing support was operationalized as the government effort to provide good networks with supermarket, accessibility of products into supermarket and tourist centres, establishing good networks with wholesaler and retailers, offering comparable quality of products, the ability to penetrate niche market, and grabbing market opportunity (Mastura, 2012; Morgan, 2012). Marketing support was measured using eight items adapted from Rogoff et al. (2004), Stevenson and St-Onge (2005), and Wijewardena and Tibbits (1999). Participants were asked to indicate their level of agreement or disagreement on whether the government provides support such as "sale promotion at state and national level" and "government-appointed distributors". A fivepoint Likert scale with anchors ranging from ' 1 ' "strongly disagree" to ' 5 ' "strongly agree" was used to measure marketing support. 
Financial support is operationalized as the management of credit and delivery of fund (Stevenson \& St-Onge, 2005). Financial support was measured using ten items adapted from Stevenson \& St-Onge (2005). All items employed a five-point scale ranging from ' 1 ' "strongly disagree" to ' 5 ' "strongly agree". Examples of items included 'application procedures', and 'management of credits'.

Business networking was operationalized as specific sets of relations amongst various groups or actors that require linkages between key players in business (Aldrich \& Zimner, 1986). This construct was measured using four items adapted from Rogoff et al. (2004) and Stevenson and St-Onge (2005). Participants were asked to indicate their level of agreement or disagreement on whether the government provides support such as "business networking with entrepreneur development agencies" and "good relationship with business association". A five-point Likert scale with anchors ranging from ' 1 ' "strongly disagree" to ' 5 ' "strongly agree" was used to measure business networking.

\section{Results}

To test for H1, H2, H3 and H4, a multiple regression was conducted. Specifically, business performance was regressed on the four independent variables, namely entrepreneurship training, financial support, marketing support and business networking. To draw accurate conclusions about the regression analysis, assumptions of linearity, homoscedasticity, normality, independence of the error terms, and multicollinearity need to be examined. Variance inflation factor (VIF) and tolerance statistics are the two statistical methods that can be used to assess multicollinearity. It is generally believed that any VIF value exceeds 10 and tolerance value below than .10 indicates a problem of multicollinearity. In addition, Durbin-Watson can be used to test independence of error terms. If the Durbin-watson value is between 1.5 and 2.5, the assumption of independence of the error terms is not violated. It this study, evaluation on assumptions of linearity, homoscedasticity, normality, independence of the error terms, and multicollinearity revealed no significant violation of assumption. Table 1 presents the results of this analysis.

It is noted that the $35.6 \%$ of the variance in business perfromance had been significantly explained by the entrepreneurship training, financial support, marketing support and business networking. $\left(\mathrm{R}^{2}=.356 ; F=4.411, p<.05\right)$. In other words, all these predictors accounted for $35.6 \%$ of the variation in the business performance among rural entrepreneurs. The finding shows that all variables had significant relationship with business performance, with business networking recording the highest beta value $(\beta=.411, \mathrm{p}<.01)$, followed by marketing support $(\beta=.326, \mathrm{p}<.05)$ and entrepreneurship training $(\beta=-.203, \mathrm{p}<.05)$ and financial support $(\beta=-.124, \mathrm{p}<.05)$.

Table 1. Multiple Regression Result

\begin{tabular}{lcc}
\hline Independent variables & $\beta$ & Sig. \\
\hline Entrepreneurship training & $-.203^{* *}$ & .021 \\
Financial support & $-.124^{*}$ & .011 \\
Marketing support & $.326^{*}$ & .016 \\
Business networking & $.411^{* *}$ & .001 \\
\hline $\mathrm{R}^{2}$ & .356 & \\
Adj. $\mathrm{R}^{2}$ & .08 & \\
F value & 4.411 & \\
\hline
\end{tabular}

Note: ${ }^{*} \mathrm{p}<.05,{ }^{* *} \mathrm{p}<.001$ 


\section{Discussion and Conclusion}

The main objective of the present study was to examine the influence of entrepreneurial initiatives on business performance of rural enterprises. Based on multiple regression result, the researcher observed a number of interesting findings. Firstly, the result found that entrepreneurship training was significantly and negatively correlated with business performance. Generally, one could expect greater entrepreneur performance when the number of training increases. One of the possible reasons for this finding would be improper planning, designing and implementing the entrepreneurships training. For instance, the negative direction could be influenced because of inadequate training program (Abdul Razak et al., 2012). They also added that any entrepreneurship intervention programs involving rural business should be sensitive to the entrepreneurs' need, as well as being designed to the specific module and local requirement, and continuity between rural entrepreneurship programs. In addition, lack of comprehensive Training Needs Analysis (TNA) could be the reason for the finding. The outcome of the training is questionable when the trainings designed do not match the trainees' expectations. This is because any entrepreneurship intervention programs involving rural business should be sensitive to the entrepreneurs' need and designed according to the specific module and local requirement, and eliminating the lack of continuity between rural entrepreneurship programs (Othman et al., 2011).

Second, it is also surprising that financial assistance was found negatively related to business performance. Since lack of funds is one of the constraints rural enterprises face, it was hypothesized that financial assistance would help them succeed in their business. However, despite having access to financial accessibility, rural entrepreneurs still face high cost of borrowings, high banks charges and fees, and high legal documentation fees associated with the assistance (Nurbani et al., 2011; Siwar et al., 1994). Although the explanation is plausible, more works need to be done to ascertain its validity. But, if indeed, the claim is correct, the government has to develop some financing policies that are conducive for the rural enterprises. Another reason that probably influences the negative direction between financial support and business performance is personality traits of entrepreneurs. According to Sandhu, Hussain and Matlay (2012), much research has been done on the influence of supportive business environment and agreed that the entrepreneurial process has attitudinal and behavioural components. Thus, in an effort to enhance rural business performance, attitudinal and behavioural aspects should be taken into consideration when evaluating entrepreneurs' performance. This is because some of the entrepreneurs did not possess qualities of risk taking in managing their capital, and ability to resolve problems when dealing with good finance management. Thus, this reason explains why the relationship between financial support and rural entrepreneurs are not as expected.

Third, the positive role of marketing support in helping rural entrepreneurs in their business is consistent with previous works (Morgan 2012). According to Mastura (2012), small-business owners normally pay less attention to marketing because they do not possess the necessary skills and knowledge to do so. So, marketing support from the government is imperative to enable them to penetrate the market, both locally and internationally, and hence, their success. Our findings also show that having business network is important for the business success of rural entrepreneurs, confirming previous results (Granovetter, 1992; Neergard et al., 2005). Through business networking, rural enterprises, which tend to have several constraints (Norhaziah \& Mohd Noor, 2011) are able to allow them to get access to resources they lack, which help them in their business (Aldrich \& Zimmer, 
1986; Ostgaard \& Birley, 1996). Even though currently there are many initiatives are provided by the government to help rural entrepreneurs market their products and services, more concerted and aggressive marketing efforts need to be made. This measure is important before the "single ASEAN market" is implemented where rural entrepreneurs will face increased competition. In this context, developing wider business network for the rural entrepreneurs that could help them not only in terms of getting access to resources but also of marketing their products and services is imperative. Encouraging the rural entrepreneurs to participate in local and international events where they can network is something the government can do to assist.

Finally, a positive relationship existed between business networking and rural entrepreneurs' business performance because rural entrepreneurs received good support from many parties such as government, and public sector agencies in various parts of business need such as support from entrepreneur development agencies and financial institutions. With this, the government has continued focussing attentions to empower entrepreneurs in the rural areas in efforts to stimulate the nation's economic growth. In order to achieve this aim, the government through Amanah Ikhtiar Malaysia (AIM) and Tekun Nasional (TEKUN) has consistently made efforts to help and develop local entrepreneurs. For example, RM12.1 billion has been spent by AIM and TEKUN to help 686,000 local entrepreneurs in the year 2013. Of the total, 565,400 or $82 \%$ of them are entrepreneurs from rural areas. In addition, between the year 2006 to 2013, the government has spent RM3.2 billion through the Rural and Regional Development Ministry and implementing agencies such as MARA, Kedah Development Authority, Johor Tenggara Development Authority and Terengganu Tengah Development Authority to implement various entrepreneurial programmes in rural areas such as technopreneurs development, integrated marketing, advisory services, entrepreneurial skills training and strategic business networking. Thus, the presence of business networking initiatives has been seen as a good platform to promote the emergence of new growing business among rural entrepreneurs. Based on all these initiatives, this particular finding does not show any surprise results.

Despite the insightful findings, the researcher cautions that they should be interpreted by taking into consideration the limitations inherent in the present study. Firstly, the study is limited by its reliance on self-reported instruments associated with validity problems (Aadahl \& Jørgensen, 2003). However, self-reported measures have been previously used (Salminen et al., 2013) and they allow researchers to obtain participants' own views directly, unobtainable in any other way. Secondly, the authorized agencies or department directly related to rural entrepreneurs do not have a complete database of rural entrepreneurs. As a result, the findings may not be generalizable to a much larger population of rural entrepreneurs. Finally, because the present study was cross-sectional nature, causal inferences may be limited; the data can only provide a "snapshot" picture of the entrepreneurial initiatives and rural business performance.

In sum, despite the limitations, we have provided some insights into the role of government support on business performance of rural entrepreneurs. Even though, generally speaking, the government support was found to enhance business performance, different kinds of support seem to have different effects, suggesting that more studies need to be conducted to confirm the finding.

\section{Acknowledgement}

This study was funded by Kementerian Pengajian Tinggi (KPT) Malaysia under the Fundamental Research Grant Scheme (FRGS). I would like to express my gratitude to Research and Innovative Management Centre 
(RIMC) UUM for their support, to all research team members, and colleagues in UUM, especially all lecturers in Human Resources Department, for sharing the knowledge and invaluable assistance.

\section{References}

Aadahl, M., \& Jørgensen, T. (2003). Validation of a new self-report instrument for measuring physical activity. Medicine E Science in Sports E Exercise, 35, 1196-1202.

Abd Razak, A., Mohd Hassan, M. O., Kamariah, I., \& Wan Fauziah, W. Y. (2012). The exploring individual resources factors toward entrepreneurial opportunity exploitation in rural entrepreneurship. Proceedings of the International Conference of Technology Management, Business and Entrepreneurship, pp. 830-841, Malaysia.

Alberti, F., Sciascia, S. \& Poli, A. (2005). The domain of entrepreneurship education: Key issues. International Journal of Entrepreneurship Education, 2(4), 453-82.

Aldrich, H., \& Zimmer, C. (1986). Entrepreneurship through social networks. In D. L. Sexton \& R. W. Smilor (Eds.), The art and science of entrepreneurship, pp. 3-23. Cambridge, MA: Ballinger.

Barney, J. (1991). Firm resources and sustained competitive advantage. Journal of Management, 17, 99-120.

Berger, A. N., Klapper, L. F., \& Udell, G. F. (2001). The ability of banks to lend to informationally opaque small businesses. Journal of Banking \& Finance, 25(12), 2127-2167.

Berger, A. N., \& Udel, G. F. (1994). Lines of credit and relationship lending in small firm finance. Jerome Leoy Economics Institute Working Paper (No. 113).

Burt, R. S. (1997). The contingent value of social capital. Administrative Science Quarterly, 42(2), 339-365.

Charney, A., \& Libecap, G. (2000). The impact of entrepreneurship education: an evaluation of the Berger Entrepreneurship Program at the University of Arizona, 1985-1999. Arizona, TX: University of Arizona.

Fatimah, A. H., Mohamad Azahari, A., \& Tamkin, B. J. (2013). Success factors of successful microcredit entrepreneurs: Empirical evidence from Malaysia. Int. Journal of Business and Social Science, 4(5), 153-168.

Florin, J., Lubatkin, M., \& Schulze, W. (2003). A social capital model of high-growth ventures. Academy of Management Journal, 46(3), 374-384.

Frazier, B. J., \& Niehm, L. S. (2004). Exploring business information networks of small retailers in rural communities. Journal of Development Entrepreneurship, 9(1), 23-35.

Garavan, T., \& O'Cinneide, B. (1994). Entrepreneurship education and training programmes: A review and evaluation - Part 2. Journal of European Industrial Training, 18(11), 13-21.

Gilmore, A., Carson, D., \& Rocks, S. (2006). Networking in SMEs: Evaluating its contribution to marketing activity. International Business Review, 15(3), 278-293.

Granovetter, M. (1992). Problems of explanation in economic sociology. In N. Nohria \& R. Eccles (Eds.), Networks and organizations: Structure, form and action (pp. 25-56). Boston, MA: Harvard Business School Press.

Hakimin, Y., Dahlan, I., \& Rafi, Y. (2010). The Sources of Information of the Government Sponsored Business Assistance Among Miro-sized Entrepreneurs in Kelantan, Malaysia. Paper presented at the 2nd ICIES, Jakarta.

Hisrich, R. D., \& Fulop, G. (1994). The role of women entrepreneurs in Hungary`s transition economy. International Studies of Management and Organization, 24(4), 100-117.

Hoe, C. H., Filzah, M. I., Cheng, W. H., Norashidah, H., Jasmani, M. Y., \& Haim Hilman, A. (2012). Development of women entrepreneurs: The case of Malaysia. World Journal of Social Sciences, 2(6), 123-145.

Hytti, U. (2008). Enterprise education and different cultural settings and at different schools levels. In A. Fayolle \& P. Kyro (Eds.), The dynamics between entrepreneurship, environment and education: European research in entrepreneurship. Cheltenham, UK: Edward Elgar Publications Ltd. 
Hyvonen, J. (2007). Strategy, performance measurement techniques and information technology of the firm and their links to organizational performance. Management Accounting Research, 18, 343-366.

Jarillo, C. J. (1989). Entrepreneurship and growth: The strategic use of external resources. Journal of Business Venturing, 4(2), 133-147.

Jones, R., \& Parry, S. (2011). Business support for new technology-based firms: a study of entrepreneurs in North Wales. International Journal of Entrepreneurial Behaviour and Research, 17(6), 645-662.

Khairudin, H. (Ed.). (2007). Small and Medium-sized Entreprises Development in Malaysia: Programs and evaluation. Sintok: Universiti Utara Malaysia.

Kuene, T. R. (2008). A critical analysis of entrepreneurial and business skills in SMEs in the textile and clothing industry in Johannesburg, South Africa. Unpublished doctoral thesis, University of Pretoria, South Africa.

Lepoutre, J., Berghe, W., Tilleuil, O. \& Crihns, H. (2010). A new approach to testing the effects of entrepreneurship education among secondary school pupils [Internet], Working Paper Series 2010/01. Leuven, Vlerick Leuven Management School. Available: http://www.vlerick.com/en/12958-VLK/version/.../vlgms-wp-2010-01.pdf

Mastura, J. (2012). Entrepreneurial marketing and accommodation business in East Peninsular Malaysia. Journal of Research in Marketing and Entrepreneurship, 14(2), 164-183.

Mohd Noor Hakimin, Y., \& Mohd Rafi, Y. (2010). The government business support services in Malaysia: the evolution and challenges in the new economic model. Int. Journal of Business and Management, 5(9), 60-73.

Morgan, N. A. (2012). Marketing and business performance. Journal of the Academic Marketing Science, 40, 102119.

Musdiana, M. S., \& Noor Zahirah, M. S. (2011). Rural entrepreneurship: A challenge and opportunities of rural micro enterprise (RME) in Malaysia. Interdisciplinary Journal of Contemporary Research in Business, 2(11), 573585.

Neergard, H., Shaw, E., \& Carter, S. (2005). The impact of gender, social capital and network on business ownership: A research agenda. International Journal of Entrepreneurial Behaviour E Research, 11(5), 338-357.

Nor Haryanti, M. N., Siti Norbaya, M. R., Rabihah, N., Fadhilah, M. I., \& Mohd Sazali, M. Z. (2012). Women entrepreneurship in micro credit performance: The preliminary study in Kelantan. Proceedings of $2^{\text {nd }}$ International Conference on Management (pp. 1282-1292). Kedah, Malaysia.

Norhaziah, N., \& Mohd Noor, M. S. (2011). The importance of micro financing to the microenterprises development in Malaysia's experience. Asian Social Science, 7(12), 226-39.

Nurbani, H., Chin, S, Yeow, J., \& Noor Ashikin, M. R. (2011). Financial constraints and opportunities of micro enterprise entrepreneurs: A theoretical framework. International Conference on Business and Economics Research, 1, 165-168.

Ostgaard, T. A., \& Birley, S. (1996). New venture growth and personal networks. Journal of Business Research, 36(1), 37-50.

Pech, R. J., \& Cameron, A. (2006). An entrepreneurial decision process model describing opportunity recognition. European Journal of Innovation Management, 9(1), 61-78.

Petridou, E., \& Glaveli, N. (2008). Rural women entrepreneurship within cooperatives: training support. Gender in Management: An International Journal, 23(4), 262-277.

Radiah, A. K., Mohd Rosli, M., \& Ab Azid, C. I. (2009). Success factors for small rural entrepreneurs under the One-District-One-Industry Programme in Malaysia. Contemporary Management Research, 5(2), 147-162.

Reijonen, H. (2008). Understanding the small business owner: what they really aim at and how this relates to firm performance: A case study in North Karelia, Eastern Finland. Journal of Small and Enterprises Development, 31(8), 616-629. 
Reijonen, H. (2010). Do all SMEs practice same kind of marketing? Journal of Small Business and Enterprise Development, 17, 279-293.

Robb, A. M., \& Robinson, D. T. (2014). The capital structure decisions of new firms. Review of Financial Studies, 27(1), 153-179.

Rogoff, E., Lee, M., \& Suh, D. (2004). Who done it? Attributions by entrepreneurs and experts of the factors that cause and impede small business success. Journal of Small Business Management, 42(4), 364-376.

Salminen, M., Vaapio, S., Raina, I., \& Kivela, S. (2013). Funcational status of olders adults in Findland: A review of the literature. The International Journal of Geriatrics and Gerantology. 8(1), 231-242

Samujh, R.H. (2011). Micro-business need support: Survival precedes sustainability. Corporate Governance, 11(1), $15-28$.

Siwar, C., Abdul Hamid, J., \& Ahmad, M. Z. (1994). Rural small scale industries: Profile, constraints and policy issues. Akademia, 44, 101-124.

Skuras, D., Caldas, J.C., Meccheri, N., Psaltopoulos, P., \& Viladomiu, L. (2003). Institutional support to strategic business orientations: an empirical analysis of rural business in four countries of southern Europe. European Business Review, 15(4), 235-244.

Smith, E. E., \& Perks, S. (2006). Training interventions needed for developing black macroentrepreneurial skills in the informal sector: A qualitative perspective. Unpublished master's thesis, Nelson Mandela Bay Metropolitan University, South Africa.

Solomon, G. (2004) Entrepreneurship and the impact of entrepreneurial orientation training on SMMEs in the South African context: A longitudinal approach. Unpublished master's thesis, University of Western Cape, South Africa.

Status and performance of Small and Medium Enterprises. (2006). Retrieved March 12, 2014 from http://www.bnm.gov.my/pdf

Stevenson, L., \& St-Onge, A. (2005). Support for growth-oriented women entrepreneurs in Uganda. Geneva: International Labour Organization.

Teoh, W. M. T., \& Chong, S. C. (2008). Improving women entrepreneurs in small and medium enterprises in Malaysia: Policy recommendations. Communications of the IBIMA, 2, 31-43.

Umrani, W. A., Kura, K. M., \& Ahmed, U. (2018). Corporate entrepreneurship and business performance. PSU Research Review.

Van de Ven, A. H., Hundson, R., \& Schroeder, D. M. (1984). Designing new business start-ups: entrepreneurial, organizational, and ecological considerations. Journal of Management, 10(1), 87-107.

Wijewardena, H., \& Tibbits, G. E. (1999). Factors contributing to the growth of small manufacturing firms: Data from Australia. Journal of Small Business Management, 37(2), 88-95.

Wilken, P. H. (1979). Entrepreneurship: A comparative and historical study. Norwood, New Jersey: Ablex Publishing Corporation.

Zhao, L., \& Aram, J. D. (1995). Networking and growth of young technology-intensive ventures in China. Journal of Business Venturing, 10(5), 349-370.

Zumilah, Z. (2012). Scaling up rural micro enterprises: Profile of owners in Peninsular Malaysia. Pertanika Journal of Social Science and Humanities, 20(4), 1049-1064.

(C) 2020 by the author(s). Published by Annals of Contemporary Developments in Management \& HR (ACDMHR), under the terms and conditions of the Creative Commons Attribution (CC BY) license which can be accessed at http://creativecommons.org/licenses/by/4.0. 